\title{
WATER QUALITY ASSESSMENT OF PAGARA RESERVOIR, JOURA, MORENA DISTRICT, MADHYA PRADESH DUSHYANT KUMAR SHARMA ${ }^{\mathrm{a} 1}$ AND RAKHI UCHCHARIYA ${ }^{\mathrm{b}}$ \\ ${ }^{\mathrm{ab}}$ Department of Zoology, Govt. Model Science College, Gwalior, M.P., India
}

\begin{abstract}
A study was undertaken to assess the water quality of Pagara reservoir, situated at Asan river, Jaura, District Morena in Madhya Pradesh. Physico-chemical properties of the reservoir were analyzed for the period June 2017 to May 2018. Water was analyzed for physical parameters like Temperature, Turbidity, Transparency, TDS and Conductivity and chemical parameters like pH, Total Hardness, Calcium and Biochemical Oxygen Demand were studied throughout the study period. The study revealed that most of the physico-chemical parameters lie in the standard values of drinking water as provide by WHO and BIS. The water of the Pagara reservoir is quite suitable for drinking purpose and fish culture.
\end{abstract}

KEYWORDS: Pagara Reservoir, Physico-chemical and Water Analysis

Water is nature's most wonderful, abundant and most useful chemical compound gifted by nature with physico-chemical and biological properties and unique characteristics. It is absolutely essential for domestic purposes for cleaning, cooking, bathing, and carrying away wastes, and in agriculture for irrigation, power generation, industries, navigation, propagation of wild life, fisheries, recreation, aesthetics etc. (Simpi et al., 2011).

The healthy aquatic ecosystem is depended on the physico chemical and biological characteristics (Venkatesharaju et al., 2010). Expanding human population brought about by the opportunities of good water supply, irrigation, fish production recreation and navigation offered by dams has put enormous pressure and stress on the quality of water impounded by the dam. The impact of human activities in and around the dam is felt on the unique physical and chemical properties of water on which the sustenance of fish that inhabit the reservoir is built as well as to the functions of the reservoir. Water quality is important in drinking water supply, irrigation, fish production, recreation and other purposes to which the water must have been impounded (Sidnei et al., 1992). Pagara dam, located on Pagara reservoir could also have affected some of the properties of the reservoir.

Water quality deterioration in reservoirs usually comes from excessive nutrient inputs, eutrophication, acidification, heavy metal contamination, organic pollution and obnoxious fishing practices. The effects of these "imports" into the reservoir not only affect the socio-economic functions of the reservoir negatively, but also bring loss of structural biodiversity of the reservoir (Mustapha, 2008).

\section{MATERIALS AND METHODS}

\section{Study Area}

Morena is one of the districts of Madhya Pradesh that forms a part of the Gwalior - Chambal division. Pagara dam is situated on Asan river at about 13 $\mathrm{Km}$ from Jaura town of Morena District (Fig.1 and 2). The dam was constructed for the irrigation of the nearby villages. It is a masonry dam which was constructed in 1931. Geographically, the dam is located at latitude $26^{\circ} 09^{\prime} 27.9^{\prime \prime} \mathrm{N}$ and longitude $77^{\circ} 48^{\prime} 22.3^{\prime \prime} \mathrm{E}$. The FTL (Full tank Level) of the dam is $199.34 \mathrm{~m}$. The dam was constructed mainly for irrigation purpose. The water is used for irrigation of 870 acre land of the nearby villages. Pagara is the nearest village, after the name of which the dam is known as Pagara dam. Besides irrigation, the water is also used for drinking purpose, and also for fish culture by local fishermen.

\section{Collection of Samples}

The water samples were collected from the four different sites of Pagara reservoir i,e. A, B, C and D (Fig. 2 ). The water samples were collected during the morning hours between 8 to $10 \mathrm{AM}$, each month for the study period from June 2017 to May 2018. The water samples were stored in dried plastic cans of 2 lit. capacity. $\mathrm{pH}$, temperature, and Transparency were determined at the site while rest of the physico-chemical parameters were determined in the laboratory by using the standard methods APHA (2005) and Trivedi and Goel (1983). 
SHARMA AND UCHCHARIYA: WATER QUALITY ASSESSMENT OF PAGARA RESERVOIR, JOURA, MORENA...

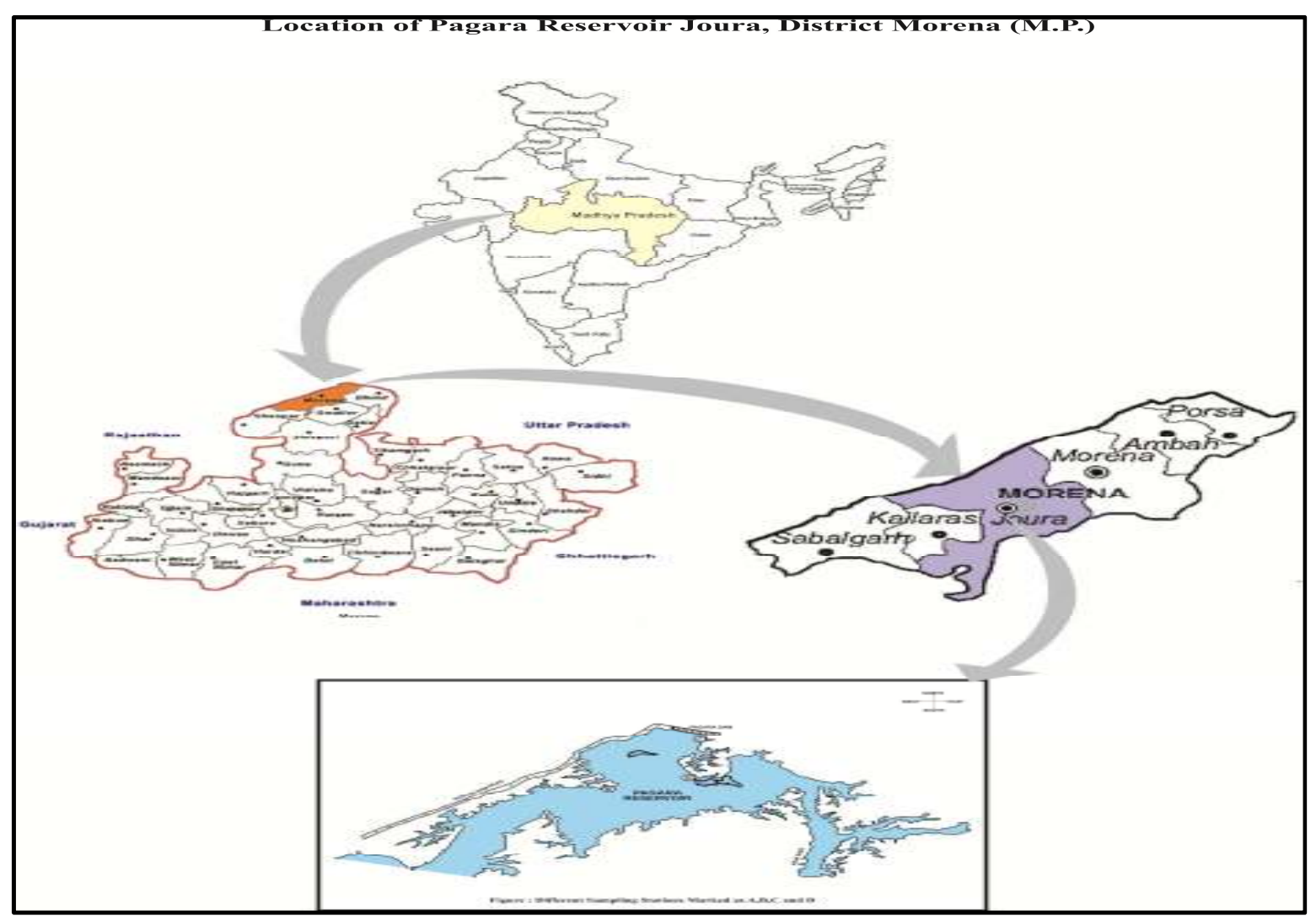

Figure 1: Location of Pagara reservoir, Jaura, District Morena (M.P.)

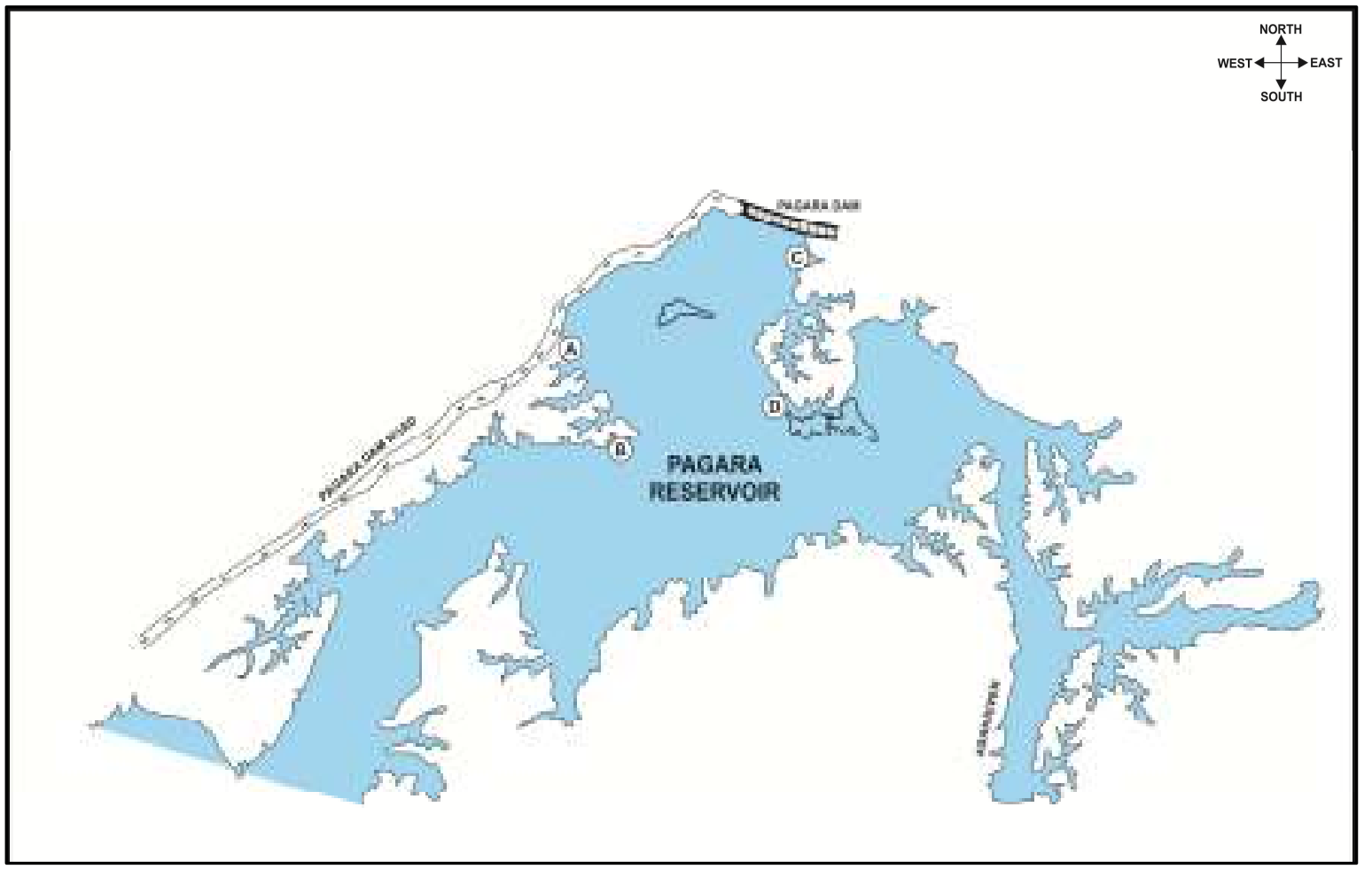

Figure 2: Different sampling stations marked as A, B, C and D 
SHARMA AND UCHCHARIYA: WATER QUALITY ASSESSMENT OF PAGARA RESERVOIR, JOURA, MORENA...

\section{RESULTS AND DISCUSSION}

figure 11.

Results are shown in Table 1 and figure 3 to

\section{Temperature}

Temperature is one of the most valuable physical factors which regulates the natural process of the environment. Temperature plays an important role in aquatic ecosystem. The temperature of drinking water has an influence on its taste. Naturally water bodies show changes in daily and seasonally due to different activities that can contribute to change in surface water temperature. In Pagara reservroir water temperature ranged from $23.85{ }^{\circ} \mathrm{C}$ to $32.07{ }^{\circ} \mathrm{C}$ during different months. During the study period maximum water temperature was recorded in summer season and minimum was recorded in winter season. Kaushik and Saksena (1999) observed water temperature between $17^{\circ} \mathrm{C}$ and $36^{\circ} \mathrm{C}$ in Ranital. Sharma et al. (2000) recorded water temperature between $21^{\circ} \mathrm{C}$ to $29^{\circ} \mathrm{C}$ in Udaipur lakes. Khaire et al. (2011) recorded water temperature in the range of $19.2^{\circ} \mathrm{C}$ to $27^{\circ} \mathrm{C}$ in Mahakari reservoir in Beed district, Maharashtra. They found water temperature to be more than the atmospheric temperature. Pentawar (2018) recorded maximum temperature during summer $\left(35.8^{\circ} \mathrm{C}\right)$ in the month of May, June and July and minimum during winter $\left(16.4^{\circ} \mathrm{C}\right)$ in the month of December and January. In Powai lake, Mitter (2018) reported water temperature in the range of $28.7^{\circ} \mathrm{C}$ to $34.8^{\circ} \mathrm{C}$. She observed high value of water temperature in summer and low in winter season.

\section{Transparency}

Transparency of water is related to the depth to which light penetrates water. Light is necessary for photosynthetic activity of aquatic plants. Transparency of water depends on the total solids, total dissolved solids and total suspended solids of the water. Transparency of Pagara reservoir varied from $158.5 \mathrm{~cm}$ to $196 \mathrm{~cm}$. Maximum transparency was recorded in winter season and minimum transparency was observed in monsoon season. Sharma (2005) has also observed maximum transparency of the water of Makroda reservoir, Guna, during winter season and it was minimum during the rainy season. Garg et al. (2010) reported transparency in the range of 66.59 to $116.00 \mathrm{~cm}$ in Ramsagar reservoir. They observed maximum transparency during winter in the month of October and minimum during monsoon season. Sharma (2017) recorded water transparency between $152.75 \mathrm{~cm}$ to $211.5 \mathrm{~cm}$ in Tighra reservoir. He also observed maximum transparency during winter and minimum during monsoon. Mitter (2018) recorded water transparency varied between $73 \mathrm{~cm}$. to $95 \mathrm{~cm}$. in Powai lake, Mumbai.

\section{Turbidity}

It is the one of the most common way to measure the extent and undecomposed organic matter, sewage and industrial waste. It is an expression of light scattering and light absorbing properties of water. Turbidity of Pagara reservoir varied from 0.47 NTU to 5 NTU. During the study period the highest turbidity was recorded during monsoon followed by summer and lowest turbidity was observed during winter season. Alam et al. (2007) observed turbidity to be highest in monsoon in Surma river. Saksena et al. (2008) recorded turbidity to be between 1 to 178 NTU in Chambal river (M.P.). Mitter (2018) measured turbidity in the range of 2.9 to $5.3 \mathrm{NTU}$ in Powai lake. In Godavari river, Pentewar (2018) mentioned minimum turbidity to be $66 \mathrm{NTU}$ and maximum turbidity to be $130 \mathrm{NTU}$ in Maharashtra. Bhoyar (2018) found turbidity in the range of 9.NTU to 21 NTU in Kudla lake, district Nanded, Maharashtra.

\section{Electrical Conductivity}

Electrical conductivity indicates the capacity of a substance or solution to conduct electrical current. Conductivity is the numerical expression of ability to carry electric current which, in turns depends on the ionic strength. It is an indicator of ionic composition. Conductivity of Pagara reservoir ranged between 162.75 $\mu \mathrm{s} / \mathrm{cm}$ and $404.25 \mu \mathrm{s} / \mathrm{cm}$. It was highest during summer and was lowest during winter . Mukherji and Nandi (2006) recorded conductivity to be more during summer season. Chandrashekhar (2006) reported water conductivity between 430 and $1720 \mu \mathrm{s} / \mathrm{cm}$. in Kondakarla lake. Chauhan and Sharma (2007) observed electrical conductivity between 0.80 to $1.65 \mathrm{mmohms} / \mathrm{cm}$. in the lake Budha, Pushkar near Ajmer, Rajasthan. Seasonally, maximum conductivity of water was observed during summer and minimum during winter. Gaur and Singh (2017) reported conductivity in the range of 350 to 450 $\mu \mathrm{s} / \mathrm{cm}$. in Ramganga river, Bareilly.

\section{Total Dissolved Solids}

Total dissolved solids is an important parameter for drinking water and water to be used for other purposes. Beyond the prescribed limit, it imparts a peculiar taste to water and reduce its portability (Mitharwal et al. 2009). Total dissolved solids in Pagara reservoir varied from 103.25 to $228 \mathrm{mg} / \mathrm{lit}$. During the 
study period maximum total dissolved solids was observed in summer and minimum in winter. Uchchariya and Saksena (2012) reported total dissolved solids to be between 81.90 and $141.75 \mathrm{mg} /$ lit in Tighra reservoir. They found maximum value of total dissolved solids during rainy season and minimum during winter season throughout the study period. Lingampally et al. (2018) also showed total dissolved solids in the range of 336 to $423 \mathrm{mg} /$ lit. in Chakki talab, Bodhan, Telangana. They found highest value of total dissolved solids during summer in the month of June and lowest during winter in the month of October.

pH

$\mathrm{pH}$ is a measure of hydrogen ion concentration in water and indicates how much water is acidic or basic. $\mathrm{pH}$ is one of the most important parameters in the chemistry of water. If the $\mathrm{pH}$ value is high it indicates that water is more corrosive nature of water can be determined with the help of $\mathrm{pH}$. There are various factors which bring about change in the $\mathrm{pH}$ of water. The average $\mathrm{pH}$ of the Pagara reservoir varied from 6.64 to 8.06. The minimum $\mathrm{pH}$ was recorded in winter season and the maximum $\mathrm{pH}$ was recorded in summer season. Bukhtar and Sakhare (2011) reported $\mathrm{pH}$ value between 8 and 8.4 with a mean of 8 in Wan reservoir in Maharashtra. Singh and Gaur (2017) also reported $\mathrm{pH}$ between 6.20 to 8.35 in Ramganga river in Bareilly. Pentewar (2018) also recorded $\mathrm{pH}$ ranged between 7.3 to 8.6 in Godavari river in Maharashtra. He found the water of Godavari river was slightly alkaline.

\section{Total Hardness}

Total hardness is predominately caused by cations of calcium, magnesium, alkaline earth metals etc. In the present study, Total hardness was recorded between $41.5 \mathrm{mg} /$ lit and $99 \mathrm{mg} /$ lit from Pagara reservoir. Shastri (2005) reported total hardness between $130 \mathrm{mg} / 1$ and $290 \mathrm{mg} / 1$ in a small percolation tank. Elamci et al. (2008) measured hardness of lake Uluabat to be in the range of $14.61 \mathrm{mg} / \mathrm{lit}$. and $140 \mathrm{mg} / \mathrm{lit}$. Saxena and Saxena (2015) recorded total hardness between $60 \mathrm{mg} / \mathrm{lit}$ and $2400 \mathrm{mg} /$ lit in Bassi tahsil, district, Jaipur, Rajashtan. Peyami (2016) observed highest value of hardness during summer and lowest during winter from Phadke Pada pond at Diva, Thane. Sharma (2017) reported total hardness of
Tighra reservoir between $66.25 \mathrm{mg} / \mathrm{lit}$ and $137 \mathrm{mg} / \mathrm{lit}$. He found maximum hardness during summer and minimum during winter.

\section{Calcium}

Calcium is an important determinant of water hardness and also functions as a $\mathrm{pH}$ stabilizer, because of its buffering qualities. According to Thilaga et al. (2005) calcium forms the most abundant ions in fresh water. In the Pagara reservoir calcium ranged between $21.02 \mathrm{mg} / \mathrm{lit}$ and $27.64 \mathrm{mg} / \mathrm{lit}$. During the study period maximum value of calcium was recorded in summer and minimum during winter season. Sathya and Shankar (2009) observed maximum value of calcium during summer and maximum during winter of karveti lake. Bade et al. (2009) also reported calcium range between 17.92 to $23.41 \mathrm{mg} / \mathrm{lit}$ of in Sai reservoir district Latur, Maharashtra. Mahajan and Pokale (2017) found calcium hardness in the range of 18 to $117 \mathrm{mg} /$ lit. of Mohabala lake near Bhadrawati. Prajapati and Rokde (2018) observed calcium in the range of 10 to $200 \mathrm{mg} / \mathrm{lit}$ in the drinking water of Indore city.

\section{Biochemical Oxygen Demand}

Biochemical oxygen demand or BOD is a measure of the quantity of oxygen consumed by microorganisms during the decomposition of organic matter. It is an important indicator of the pollution status of a water body. Biochemical oxygen demand has been used as a major of organic materials in an aquatic medium which support growth of microorganism. In Pagara reservoir, biochemical oxygen demand ranged between 0.56 and $5.54 \mathrm{mg} / \mathrm{lit}$. Seasonally, biochemical oxygen demand was maximum during summer season and minimum biochemical oxygen demand was recorded during winter season. Kamat et al. (2006) recorded the BOD values between 1.23 to $4.5 \mathrm{mg} / \mathrm{lit}$ in Husali tank and between 4.8 to $32.00 \mathrm{mg} / \mathrm{lit}$ in Purle tank, district Shimoga, Karnataka. They observed maximum BOD during summer and minimum during monsoon. Peyami (2016) measured BOD to be maximum in summer and minimum during winter season in Phadke Pada pond at Diva, Thane. Pentawar (2018) recorded BOD in the range of 6.1 to $43.0 \mathrm{mg} / \mathrm{lit}$ in Godavari river, district, Nanded, Maharashtra. 
SHARMA AND UCHCHARIYA: WATER QUALITY ASSESSMENT OF PAGARA RESERVOIR, JOURA, MORENA...

Table 1: Average Values of four different sites of various Parameters of Pagara Dam, District Morena, M.P. from June 2017 to May 2018

\begin{tabular}{|c|c|c|c|c|c|c|c|c|c|}
\hline Months & $\begin{array}{c}\text { Temp. } \\
(\mathbf{} \mathbf{c})\end{array}$ & $\begin{array}{c}\text { Trans. } \\
(\mathbf{c m})\end{array}$ & $\begin{array}{c}\text { Turb. } \\
(\mathbf{N T U})\end{array}$ & $\begin{array}{c}\text { Cond. } \\
(\mathbf{\mu s})\end{array}$ & $\begin{array}{c}\text { TDS } \\
(\mathbf{m g} / \mathbf{l})\end{array}$ & $\mathbf{p H}$ & $\begin{array}{c}\text { Hard. } \\
(\mathbf{m g} / \mathbf{l})\end{array}$ & $\begin{array}{c}\text { Cal. } \\
(\mathbf{m g} / \mathbf{l})\end{array}$ & $\begin{array}{c}\text { BOD(mg/ } \\
\mathbf{l})\end{array}$ \\
\hline Jun. 17 & 31.55 & 176 & 4.1 & 320 & 123 & 8.06 & 99 & 27.32 & 1.52 \\
\hline Jul. 17 & 32.07 & 162 & 2.12 & 242.75 & 127 & 7.77 & 77.5 & 27.52 & 2.14 \\
\hline Aug. 17 & 30.52 & 158.5 & 2.47 & 243.25 & 123.75 & 7.71 & 79 & 24.23 & 2.32 \\
\hline Sep. 17 & 28.75 & 167 & 5 & 212.5 & 116.75 & 7.62 & 75.5 & 23.38 & 1.53 \\
\hline Oct. 17 & 26.4 & 182 & 0.52 & 196.25 & 115 & 7.26 & 64 & 21.32 & 0.82 \\
\hline Nov. 17 & 25.2 & 185.5 & 1.7 & 193.25 & 112.25 & 6.64 & 45.5 & 21.23 & 0.74 \\
\hline Dec. 17 & 24.3 & 196 & 0.47 & 162.75 & 103.25 & 6.87 & 41.5 & 22.94 & 0.56 \\
\hline Jan. 18 & 24.3 & 190.5 & 0.53 & 191.25 & 122.75 & 7.62 & 49.5 & 21.02 & 0.92 \\
\hline Feb. 18 & 23.85 & 183.62 & 0.69 & 218 & 137.75 & 7.52 & 43 & 21.39 & 1.72 \\
\hline Mar.18 & 26.42 & 181.5 & 1.04 & 249.5 & 185 & 7.23 & 51 & 21.19 & 1.84 \\
\hline Apr. 18 & 27.82 & 178 & 3.32 & 345.5 & 194 & 7.67 & 66.5 & 23.33 & 2.1 \\
\hline May 18 & 29.92 & 177.5 & 4.32 & 404.25 & 228 & 7.85 & 89.5 & 27.64 & 5.54 \\
\hline Minimum & $\mathbf{2 3 . 8 5}$ & $\mathbf{1 5 8 . 5}$ & $\mathbf{0 . 4 7}$ & $\mathbf{1 6 2 . 7 5}$ & $\mathbf{1 0 3 . 2 5}$ & $\mathbf{6 . 6 4}$ & $\mathbf{4 1 . 5}$ & $\mathbf{2 1 . 0 2}$ & $\mathbf{0 . 5 6}$ \\
\hline $\begin{array}{c}\text { Maximu } \\
\text { m }\end{array}$ & $\mathbf{3 2 . 0 7}$ & $\mathbf{1 9 6}$ & $\mathbf{5}$ & $\mathbf{4 0 4 . 2 5}$ & $\mathbf{2 2 8}$ & $\mathbf{8 . 0 6}$ & $\mathbf{9 9}$ & $\mathbf{2 7 . 6 4}$ & $\mathbf{5 . 5 4}$ \\
\hline
\end{tabular}

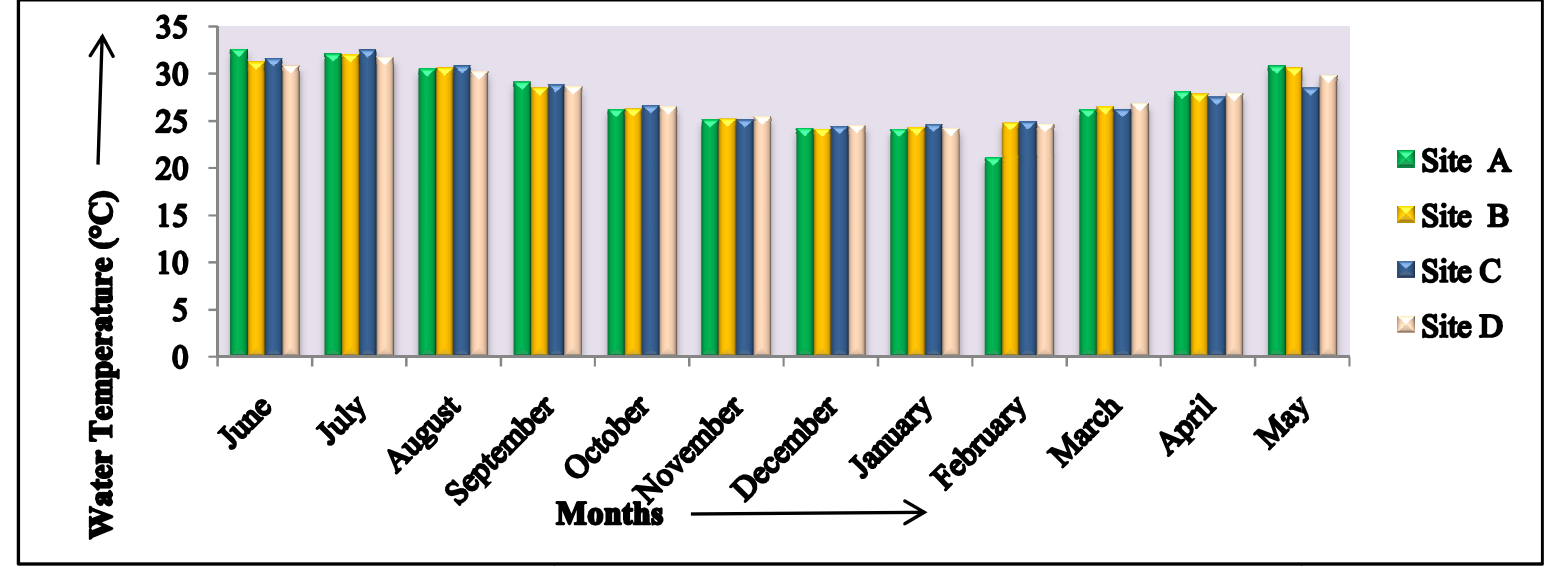

Figure 3: Monthly variations in Water Temperature $\left({ }^{\circ} \mathrm{C}\right)$ water of Pagara reservoir,from June 2017-May 2018

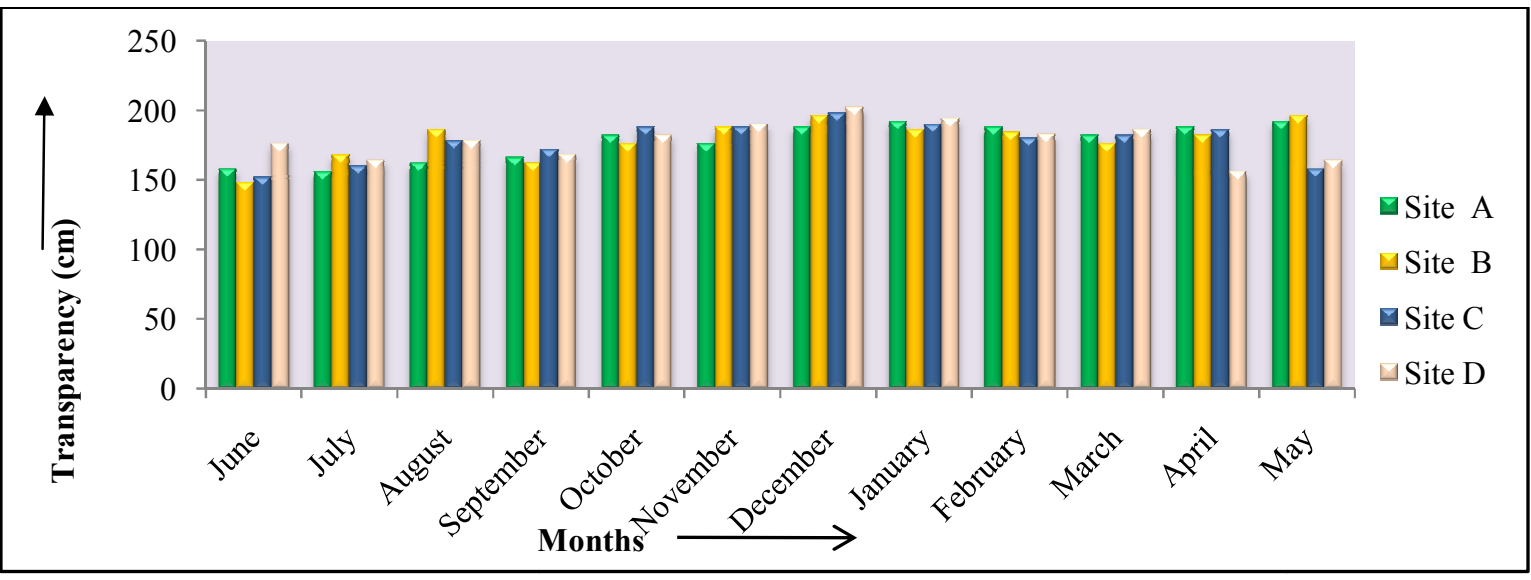

Figure 4: Monthly variations in Transparency $(\mathrm{cm})$ water of Pagara reservoir, from June 2017 to May 2018 


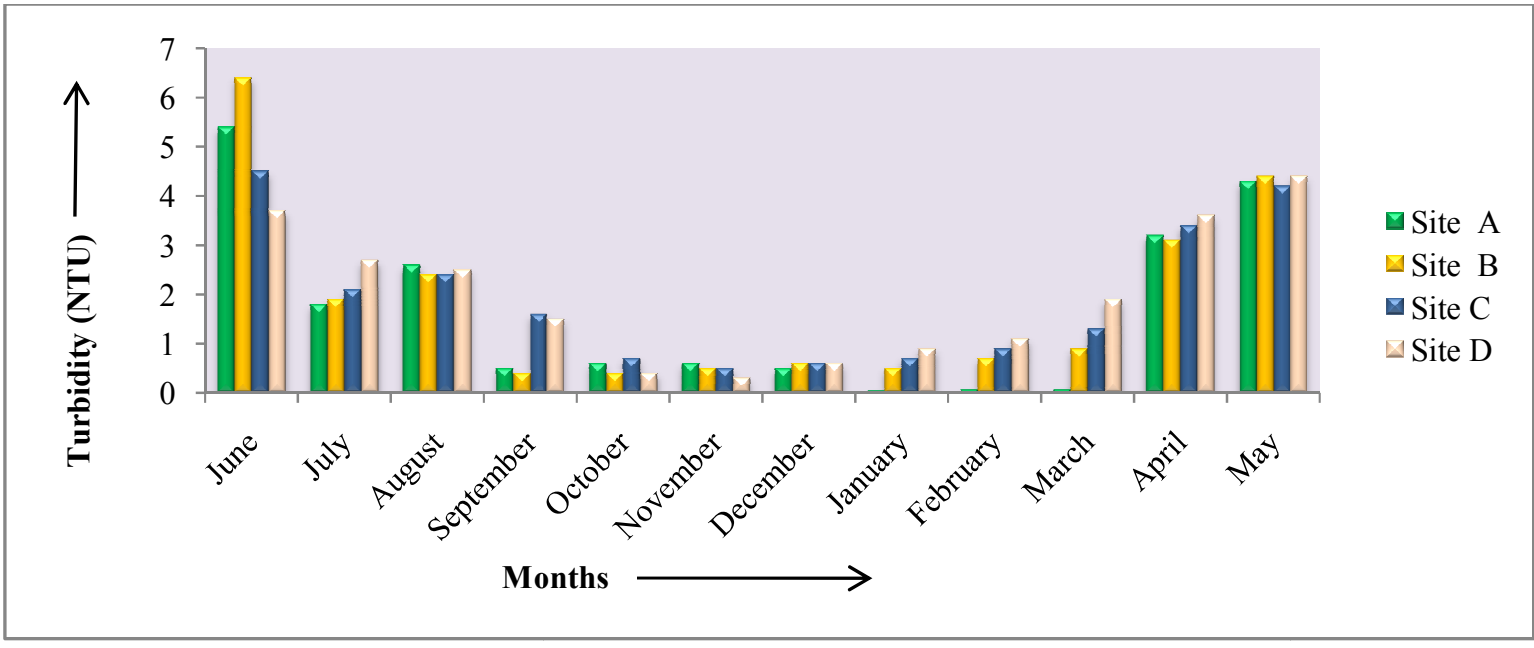

Figure 5: Monthly variations in Turbidity (NTU) water of Pagara reservoir, from June 2017-May 2018

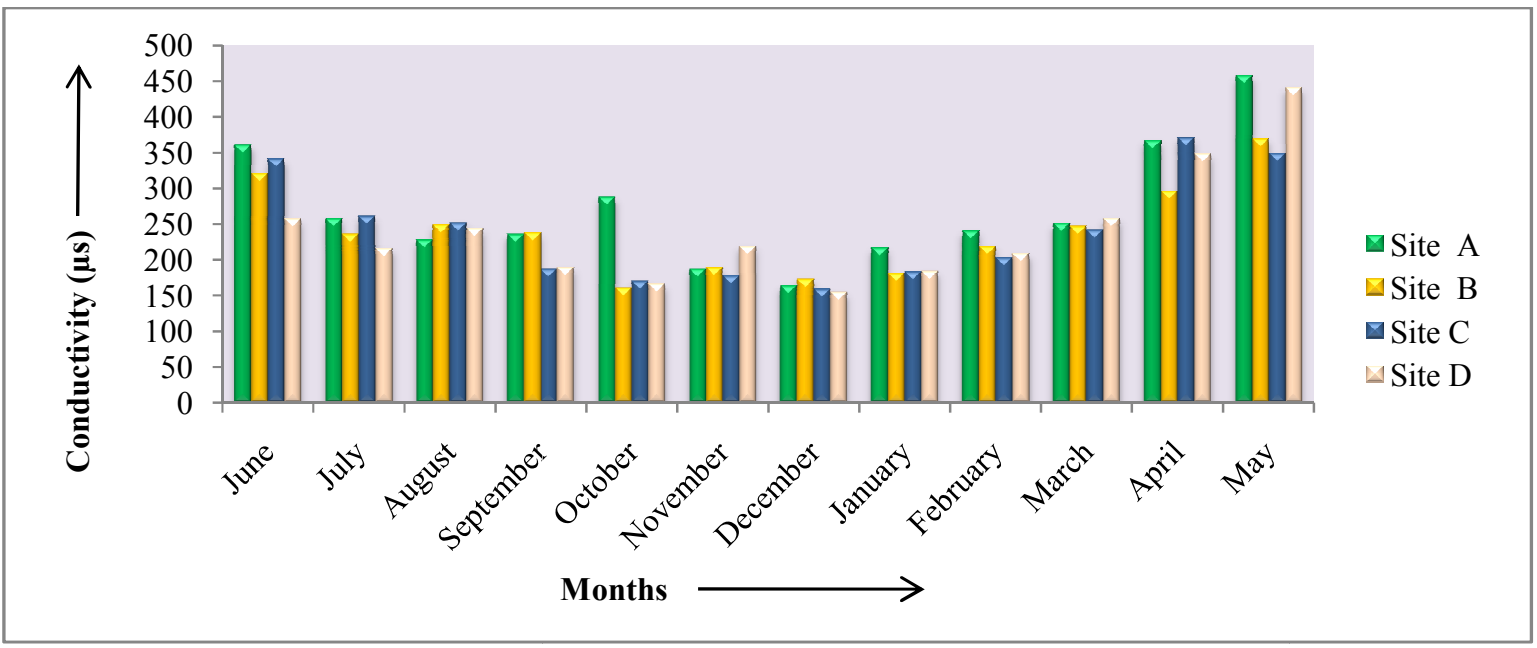

Figure 6: Monthly variations in Conductivity $(\mu s)$ water of Pagara reservoir, from June 2017-May 2018

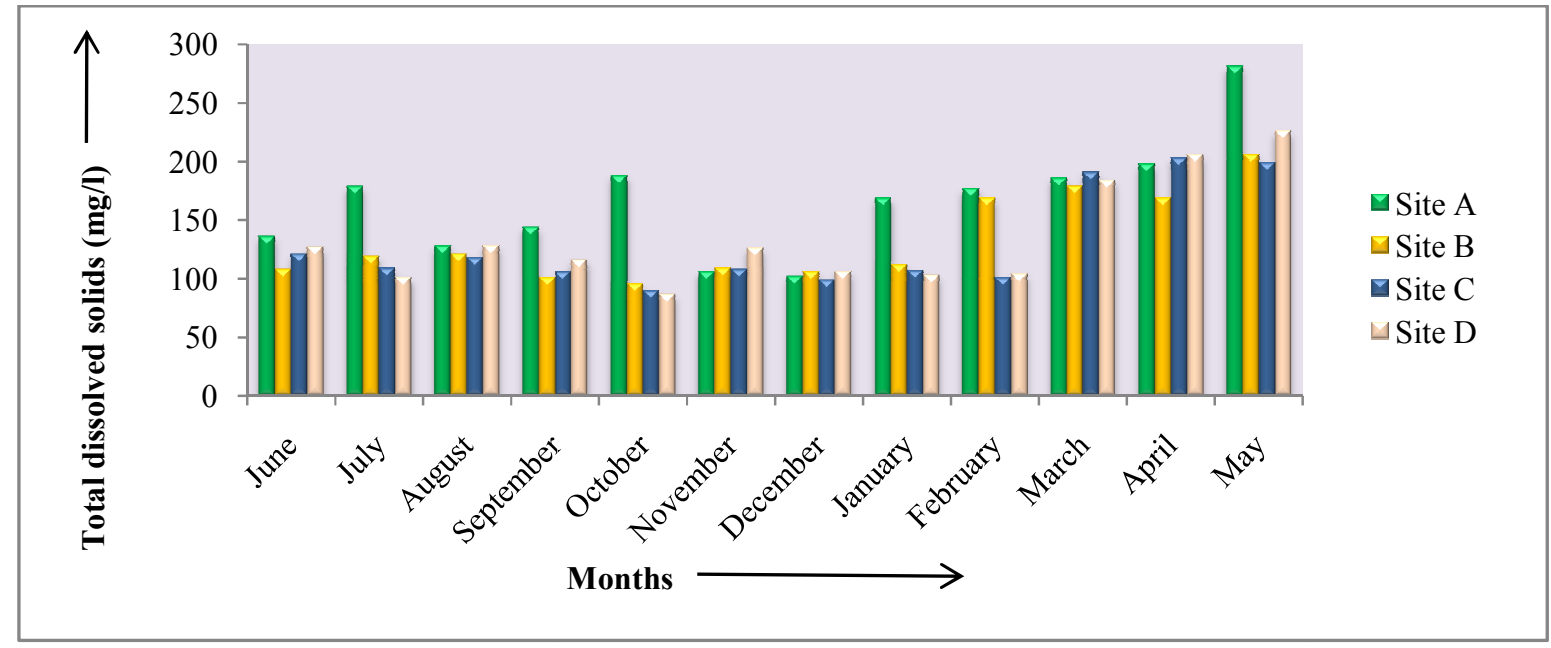

Figure 7: Monthly variations in Total dissolved solids (mg/l) water of Pagara reservoir, from June 2017-May 2018 


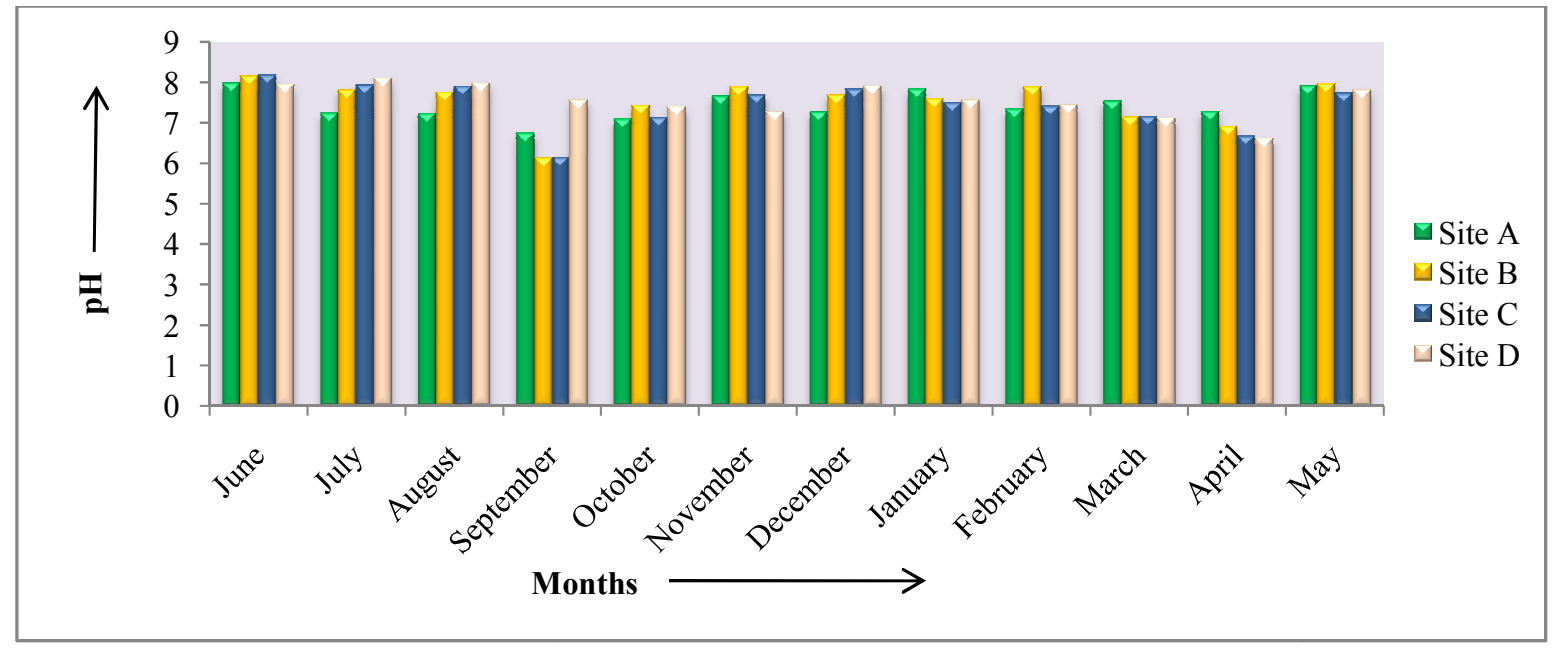

Figure 8: Monthly variations in pH water of Pagara reservoir, from June 2017-May 2018

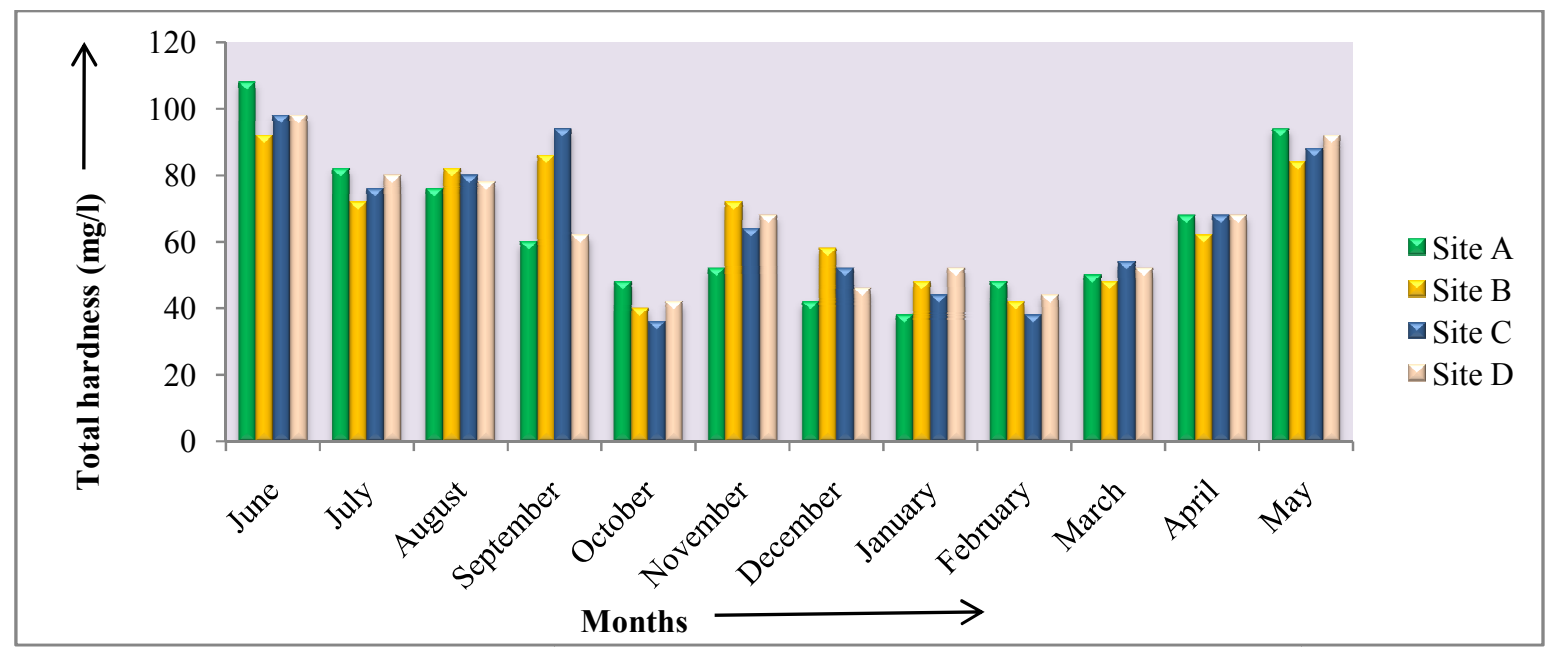

Figure 9: Monthly variations in Total hardness (mg/l) water of Pagara reservoir, from June2017-May 2018

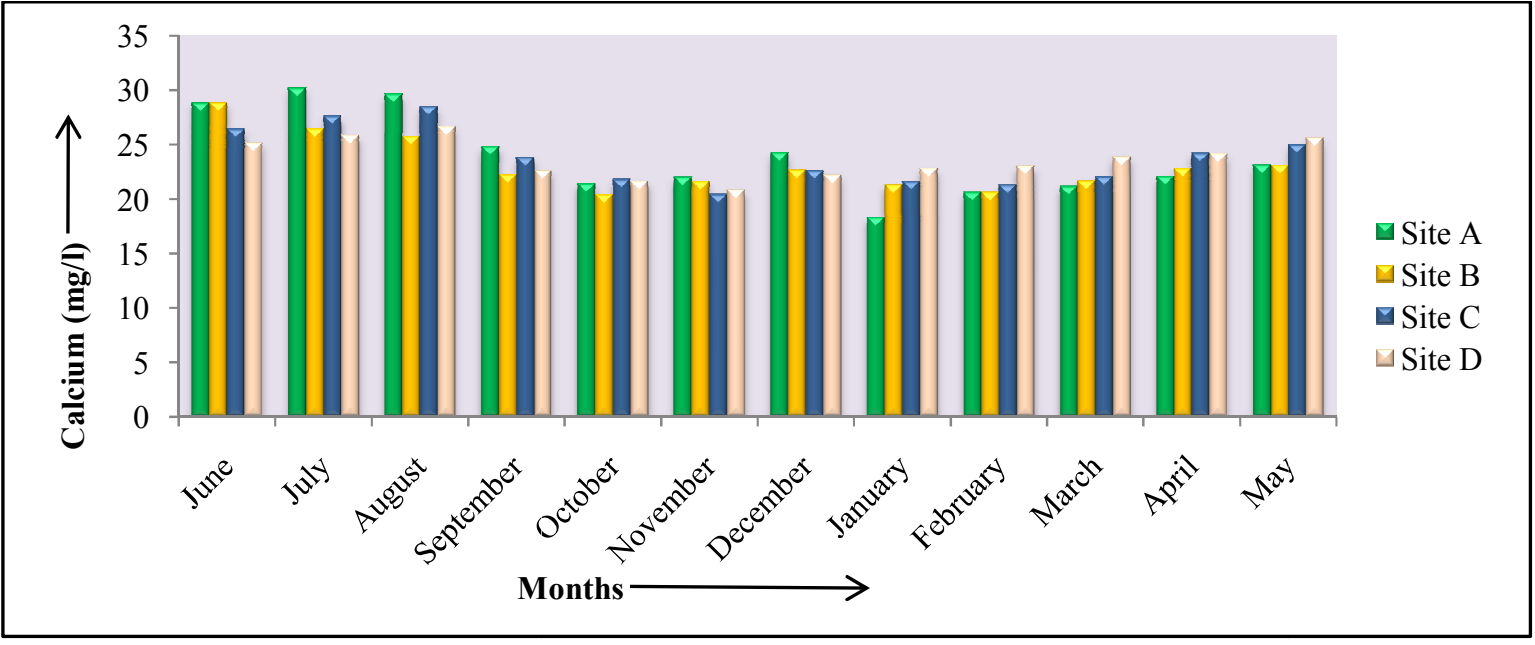

Figure 10: Monthly variations in Calcium (mg/l) water of Pagara reservoir, from June 2017-May 2018 


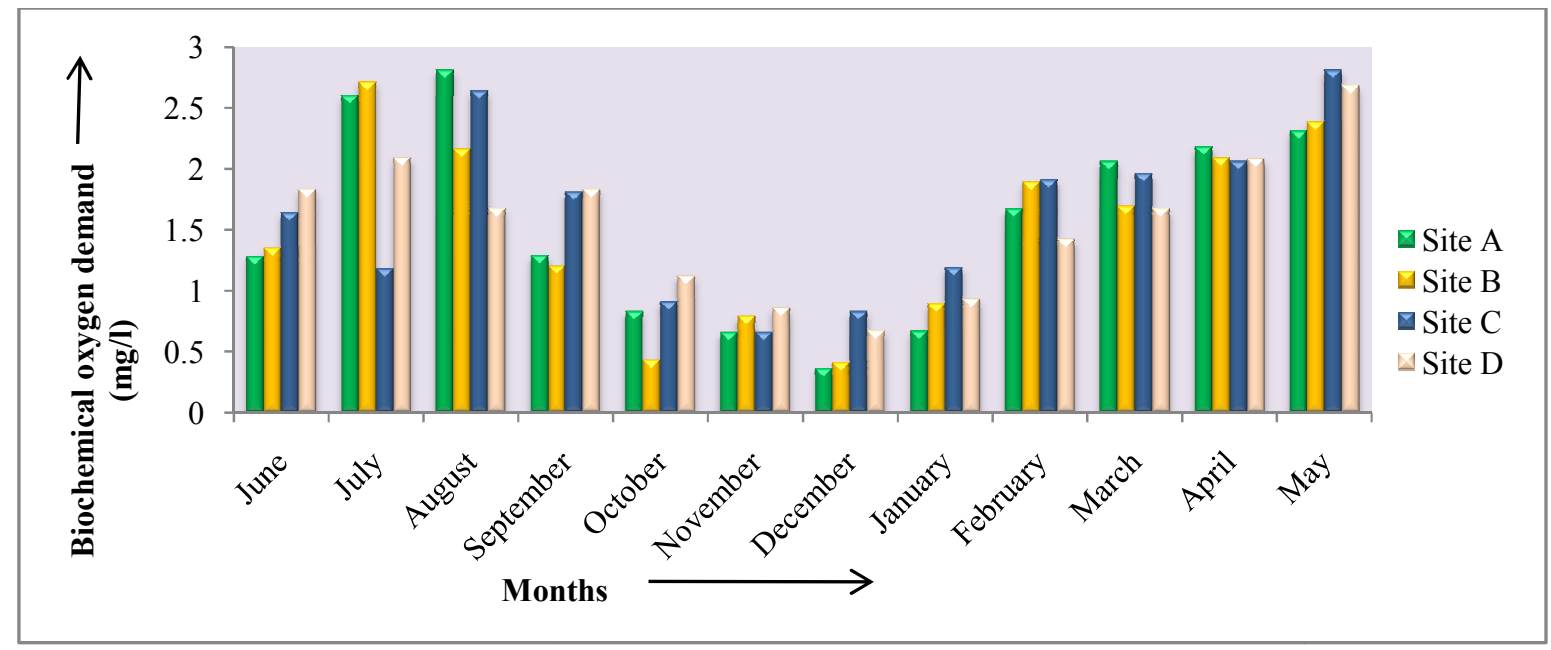

Figure 11: Monthly variations in Biochemical oxygen demand (mg/l) water of Pagara reservoir, from June 2017May 2018

\section{CONCLUSION}

In the present study most of the physicochemical parameters ranged in permissible limit of drinking water. The study indicates that the water of Pagara reservoir is suitable for drinking purpose. Different parameters indicate that the water is also suitable for fish culture and agriculture.

\section{ACKNOWLEDGEMENT}

The second author Rakhi Uchchariya is thankful to UGC, New Delhi for the award of Rajiv Gandhi National Fellowship for SC, for carrying out this study.

\section{REFERENCES}

Alam J.B., Hussain A., Khan S.K., Banik B.K., Islam M.R., Muyen Z. and Rahman M.H., 2007. Deterioration of water quality of Surma river. Environ. Monit. Assess., 134(1-3): 233-242.

APHA, 1989. Standard methods for the examination of water and waste water 17 thedition. American Public Health Association, Washington D.C.

Bade B.B., Kulkarni D.A. and Kumbhar A.C., 2009. Studies on Physcico-chemical parameters in Sai reservoir, Latur district, Maharashtra. Int. Res. Jour., 7(2): 31-34.

Bhoyar V.V., 2018. Seasonally and biological characteristics of freshwater lake Kudla Near Umri dist. Nanded (Maharashtra), India. Int. J. Life. Sci., 6(1): 295-298.
Bukhtar P.P. and Sakhare, 2011. Studies on physicochemical parameters of Wan reservoir on Beed District, Maharashtra. In: Limnology: Current Perspective (Ed. V.B.Sakhare). Daya Publishing House, Delhi, pp. 18-22.

Elmaci A., Topac F.O., Ozengin N., Teksoy A., Kurtoglu S. and Baskaya H.S., 2008. Evaluation of physical, chemical and microbiological properties of lake usuabat Iurkeg. J. Environ. Biol., 29(2): 205-210.

Garg R.K., Rao R.J. and Saksena D.N., 2009. Water quality and conservation management of Ramsagar reservoir, Datia, Madhya Pradesh. Journal of Environmental Biology, 30(5): 909916.

Garg R.K., Rao R.J., Uchchariya D., Shukla G. and Saksena D.N., 2010. Seasonal variation in water quality and major threats to Ramsagar reservoir, India. African. J. Envtal. Sci. Tech., 2(4): 61-76.

Kaushik S. and Saksena D.N., 1999. Physcico-chemical limnology of certain water bodies of central India. In: Freshwater ecosystem of India. Ed. K. Vijaykumar, Daya Publishing House, Delhi, pp.1-58.

Khaire B.S., Mohekar A.D. and Chavan R.J., 2011. Assessment of physico-chemical parameters and fish diversity of Mehakari reservoir in Beed district, Maharashtra. In: Limnology Current Perspective Ed. V.B. Sakhare, Daya Publishing House, New Delhi, pp.201-206. 


\section{SHARMA AND UCHCHARIYA: WATER QUALITY ASSESSMENT OF PAGARA RESERVOIR, JOURA, MORENA...}

Lingampally V., Solanki V.R., Jayaram V. and Sabita R.S., 2018. Study of some physico- chemical water quality parameters of Chakki talab, Bodhan, telangana. Int. J Life. Sci., 1(6): 276278.

Mahajan V.S. and Pokale S.S., 2017. Studies on physicochemical analysis of Mohabala lake near Bhadrawati, district Chandrapur (M.S.), India. Int. J Life. Sci., 3(5): 438-446.

Mitter C., 2018. Status of water quality of Powai lake, Maharashtra, India. Int. J. Sci. Res., 1(7): 1623 1625 .

Mustapha M.K., 2008. Assessment of the Water Quality of Oyun Reservoir, Offa, Nigeria, Using Selected Physico-Chemical Parameters. Turkish Journal of Fisheries and Aquatic Sciences, pp. 309-319.

Pentewar M.S., 2018. Physico-chemical aspects of Godavari river at Nanded district (M.S.), India. Int. J. Life. Sci., Special Issue A10: 174-176.

Peyami F.Y. 2016. Studies on seasonal variations in physico-chemical parameters of Phadke Pada pond at Diva, Thane, India. Int. J. Life. Sci., 4(2): 281-284.

Prajapati R. and Rokde R., 2018. Study of correlation of drinking water in Indore city (M.P.). Int. J. Sci. Res., 1(7): 2020-2022.

Saksena D.N., Garg R.K. and Rao R.J., 2008. Water quality and pollution status of Chambal river in National Chambal Sanctuary, Madhya Pradesh. J. Environ. Biol., 29(5): 701-710.

Sathya R. and Shankar P., 2009. Status of lake water quality in Karavetti. J. Basic. App. Bio., 3(1\&2): 36-41.

Saxena U. and Saxena S., 2015. Correlation study on physico-chemical parameters and quality assessment of ground water of Bassi tehsil of district Jaipur, Rajasthan, India. Int. J. Envt. Sci. Tech., 1(1): 78-91.

Sharma D.K., 2007. Studies on the Ecology and Fish fauna of Makroda reservoir of Guna district,
(Madhya Pradesh). In: Advances in Aquatic Ecology Vol. I Ed. V.B. Sakhare, Daya Publishing House, New Delhi. pp. 31-34.

Sharma D.K., 2017. Limnological studies of Tighra reservoir, Gwalior, (M.P.). Astral. Int. Pvt. Ltd. New Delhi.

Shastri Y., 2005. Physico-chemical characteristics of a small Percolation tank. Advances in Limnology Ed. S.R. Mishra, Daya Publishing House, New Delhi, pp. 253-258.

Sidnei M.T., Fakio A.L.T., Maria C.R., Francises A.E. and Adaunto F., 1992. Seasonal variation of some limnological factors of Lagoa does Guarana, a Varzea lake of the Rio Paranana State of Mato Groso do Sul, Brazil. Rev. Hydrobiol., 25(4): 269-276.

Simpi B., Hiremath S.M., Murthy K.N.S., Chandrashekarappa K.N., Patel A.N. and Puttiah E.T., 2011. Analysis of Water Quality Using Physico-Chemical Parameters Hosahalli Tank in Shimoga District, Karnataka, India. Global Journals Inc., USA, 11(3).

Singh P. and Gaur A., 2017. Physico-chemical and biological characteristics of river Ramganga at Bareilly. Int. J. Curr. Res., 12(9): 62249-62252.

Thirupathaiah M., Samatha C. and Sammaiah C., 2012. Analysis of water quality using physicochemical parameters in lower Manair reservoir of Karimnagar district, Andhra Pradesh. Int. J. Envt. Sci., 1(3):172-180.

Uchchariya D.K. and Saksena D.N., 2012. Study of nutrients and trophic status of Tighra reservoir, Gwalior, (M.P.), India. J. Natural. Sci. Res., 2(8): 97-110.

Venkatesharaju K., Ravikumar P., Somashekar R.K. and Prakash K.L., 2010. Physico-chemical and Bacteriological Investigation on the river Cauvery of Kollegal Stretch in Karnataka. Journal of science Engineering and technology, 6(1): 50-59.

WHO, 1984. International standards for drinking water. World Health Organization Technical Report. 